\title{
Perceptions Of Accountants And Prospective Accountants About Islamic Accounting Based On The Characteristics And Objectives Of Islamic Accounting
}

\author{
Henny Zurika Lubis ${ }^{1}$, Ayu Sri Wahyuni² \\ \{hennyzurika@umsu.ac.id ${ }^{1}$ \} \\ ${ }^{1}$ University of Muhammadiyah Sumatera Utara, Jln. Mukhtar Basri No.3 Medan, Indonesia \\ ${ }^{2}$ Department of Accounting, The Facukty Economic and Bisnis, Indonesia

\begin{abstract}
This study aimed to determine the perceptions of accountants and prospective accountants about Islamic accounting in terms of the characteristics and objectives of Islamic accounting. The research method used was a survey method with data collection techniques using questionnaires given to respondents where the respondents consisted of corporate accountants who worked on Islamic banks, accounting educators and accounting students from several Islamic universities in Medan.The techniques used to test hypotheses were one sample t-test, and independent sample t-test. Based on statistical tests performed, the findings of this study were: 1) Islamic accounting characteristics were not the same as conventional accounting characteristics according to the perceptions of corporate accountants, accounting educators and accounting students, 2) the purpose of Islamic accounting was not the same as conventional accounting according to the perceptions of corporate accountants, accounting educators and accounting students, and 3) there was no significant difference in perception among corporate accountants, accounting educators and accounting students about the characteristics of Islamic accounting and the purpose of Islamic accounting.
\end{abstract}

Keywords: Islamic accounting, the characteristics of Islamic accounting, the purpose of Islamic accounting

\section{Introduction}

Islamic economics is based on an Islamic view that is different from the secular view of free market capitalism(Belabes, Belouafi and Daoudi, 2015). The Islamic view is like an operating system behind the Islamic perspective on physical, social, moral, economic and metaphysical realities(Amran et al., 2014). Therefore, secular and Islamic perspectives on reality, truth, wisdom and purpose of life are different(Akhtyamova, Panasyuk and Azitov, 2015). There is an increasing interest in the study of accounting in an Islamic perspective. (Hidayah, Lowe and Woods, 2018) One aspect that drives it is the emergence of Islamic financial institutions such as Islamic banks, Islamic insurance, sharia pawnshops, sharia cooperatives, Baitul Mal Wattamwil (BMT), On the other hand, conventional aspects of accounting cannot be applied to institutions that use Islamic principles, both from accounting implications and economic consequences(Ather and Ullah, 2009). Several studies had been conducted, such as providing the basis that differences in views and values will provide different goals and characteristics in accounting (Siswantoro, Hameed and Ibrahim, 2013). Islam provides clear and rich views of values which have implications for the goals and characteristics of Islamic accounting, which are expected to be better for Islamic institutions in achieving their goals.(Shahul Hameed and Rizal, 2005). Respondents also considered that the level of importance of user accounting information between Islamic accounting and 
conventional accounting was different(Kamla, Gallhofer and Haslam, 2006) .This study aimed to re-examine the perceptions of corporate accountants, educator accountants and prospective accountants for the goals and characteristics of Islamic accounting(Trokic, 2015). Islamic accounting as a relatively young scientific discipline has become a current issue that needs to be known by accountants and efforts to advance Islamic economics are through understanding Islamic economics and accounting through lectures(Napier, 2009) Campus is one of the learning places for students in acquiring knowledge and also as a medium for delivering learning information on issues related to Islamic accounting (Kamla and Haque, 2017). If students get sufficient knowledge and understanding of Islamic accounting, students will have perceptions that are in accordance with the application of Islamic accounting itself. This can make a positive impact to increase the growth of banks in Indonesia through human resources who are able to analyze Islamic-principled businesses, especially in the banking world. On the other hand, accounting lecturers who teach at Islamic universities in Medan, based on their ability to analyze Islamic accounting, should be able to help the growth of human resources for Islamic banking so as to increase the growth of Islamic banks in Indonesia. Besides that, we also see the perceptions of corporate accountants who have run the accounting profession in leading Islamic banks in Medan based on their experiences, feelings and expectations.

Based on the description of the background above, the problems raised in this study were:

1. Were Islamic accounting characteristics the same as conventional accounting characteristics according to the perceptions of corporate accountants, accounting educators and accounting students?

2. Was the aim of Islamic accounting the same as the purpose of conventional accounting according to the perceptions of corporate accountants, accounting educators and accounting students?

3. Were there any differences in perception among corporate accountants, accounting educators and accounting students about the characteristics of Islamic accounting and the purpose of Islamic accounting?

\section{Theoretical Framework}

\subsection{Islamic accounting}

\subsubsection{Definition of Islamic Accounting}

Islamic accounting in its modern context can be defined as the accounting process which provides the necessary information to stakeholders enabling them to ensure that their entity is continuously operating under Islamic or Shari'ah Law, while fulfilling its socio-economic objective (Trokic, 2015). Accounting has always been associated with the "language of business" due to its important role in business's decision making. Hence, being the language of business, accounting itself must be dynamic in its own characteristic.(Amran et al., 2014) So, the writer concludes that Islamic accounting is an accounting product whose procedures, techniques, systems and foundations are based on rules derived by Allah SubhanaWaTa'ala through his Messenger Muhammad Salihahu 'AlaihiWassalam (Al-Qur'an and Hadith).(Accounting and Elgar, 2015). If the accounting system contains mainly extraneous values to those of the host society, the information produced may result in incorrect economic behavior, which also leads to the achievement of incompatible socioeconomic objectives(Suandi, 2013). 
Table 1. Differences in Islamic Accounting and Conventional Accounting

\begin{tabular}{|c|c|c|}
\hline & $\begin{array}{l}\text { Conventio } \\
\text { nal } \\
\text { Accountin } \\
\mathrm{g}\end{array}$ & $\begin{array}{l}\text { Islamic } \\
\text { Accountin } \\
\mathrm{g}\end{array}$ \\
\hline Purpose & $\begin{array}{l}\text { Providing } \\
\text { information } \\
\text { whose main } \\
\text { purpose is to } \\
\text { allocate } \\
\text { available } \\
\text { resources } \\
\text { efficiently } \\
\text { within the } \\
\text { framework of } \\
\text { the market } \\
\text { efficiency } \\
\text { hypothesis } \\
\text { used by users } \\
\text { in buying and } \\
\text { selling ing in } \\
\text { decisions } \\
\text { their investments. } \\
\text { inving }\end{array}$ & $\begin{array}{l}\text { Ensure that } \\
\text { Islamic } \\
\text { organizations } \\
\text { adhere to } \\
\text { sharia } \\
\text { principles and } \\
\text { try to achieve } \\
\text { certain socio- } \\
\text { economic } \\
\text { goals in } \\
\text { accordance } \\
\text { with Islam. }\end{array}$ \\
\hline Entity Postulate & $\begin{array}{l}\text { Separation } \\
\text { between } \\
\text { business and } \\
\text { owner. }\end{array}$ & $\begin{array}{l}\text { Entity is } \\
\text { based on } \\
\text { profit sharing. }\end{array}$ \\
\hline $\begin{array}{l}\text { Going } \\
\text { Postulate }\end{array}$ & $\begin{array}{l}\text { Continuous } \\
\text { business } \\
\text { continuity is } \\
\text { based on the } \\
\text { realization of } \\
\text { the existence } \\
\text { of assets. }\end{array}$ & $\begin{array}{l}\text { Business } \\
\text { continuity } \\
\text { depends on } \\
\text { contract } \\
\text { agreement } \\
\text { between the } \\
\text { groups } \\
\text { involved in } \\
\text { each profit } \\
\text { sharing } \\
\text { activity. }\end{array}$ \\
\hline $\begin{array}{l}\text { Accounting } \\
\text { postulate }\end{array}$ & $\begin{array}{l}\text { Cannot wait } \\
\text { until the end of } \\
\text { the company's } \\
\text { life by } \\
\text { measuring the } \\
\text { success of the } \\
\text { company's } \\
\text { activities. }\end{array}$ & $\begin{array}{l}\text { Every year, it } \\
\text { is subjected to } \\
\text { zakat except } \\
\text { for } \\
\text { agricultural } \\
\text { products } \\
\text { which are } \\
\text { calculated }\end{array}$ \\
\hline
\end{tabular}


Source: Muhammad (2002, p. 116) in Aprilia Ratna Puspita Sari (2010)

\subsubsection{Characteristics of Islamic Accounting}

(Hamid, Craig, \& Clarke, 1993) Religion enjoys the potential to have a less than universal acceptance within national boundaries yet the capacity to transcend them. A complex factor, it is as likely to confound as it is to explicate analyses based on indigenous national characteristics. According (Kamla, 2009) that the professionalism of business closely adheres to the character in him. Namely:

a. Siddiq (Honest). The honesty of the prophet as a businessman can be explained as follows :

1) Do not break the promised agreement

2) Do not hide defects from something that is transacted

3) Do not fool market prices

b. Amanah (trustworthy). In this context, trust is not to reduce or add something from what is supposed or agreed upon.

c. Fatanah (intelligent). In muamalah transactions, the principles of fatanah are reflected in:

1) Administering transaction documents

2) Maintaining professionalism and quality of service

3) Creative and innovative

4) Anticipating changes that occur in the market

d. Tabligh (able to deliver). By the nature of Tabligh, Islamic accounting should be able to convey the right information without leaving the honesty and truth(transparency and fairness).

(Shahul Hameed and Rizal, 2005) Islam is premised on ethical and moral conduct. This can be inferred from the Hadith narrated by Abu Hurairah, saying that the Prophet Muhammad (pbuh) has been sent only for the purpose of perfecting good morals. Naqvi (1981) views that the Islamic ethical and moral code of conduct permeates human life whether individual or collective in a way that Islam considers ethics as an offshoot of the Muslim belief system itself. Siddiqi (1979) notes that 'adala (justice) and Ihsan (benevolence) (Al-Qur'an 2:177; $5: 8 ; 4: 36)$ could be considered as the summary of the entire morals in the economic enterprise derived from the Qur'an. These values, in his opinion, are the basic values, which offer guidance in almost every action in human life. Therefore, Islamic business should also be characterized with these manners. These twin concepts of justice and benevolence need some elaboration and will be discussed further.

\subsubsection{Islamic Accounting Objectives}

Different approaches in developing accounting have resulted in different objectives of Islamic accounting. The AAOIFI (Hidayah, Lowe and Woods, 2018), for instance, with its inductive approach has proposed objectives, which are similar to the current objectives of accounting practice based on the decision usefulness approach. Meanwhile, others (i.e. Hameed, 2000a; Adnan and Gaffikin, 1997), who develop it with different approaches, have also come up with other different objectives as well(Shahul Hameed and Rizal, 2005)

\subsection{Research Methods}


The research method used was a survey. Research data on this method could be in the form of subject data that stated opinions, attitudes, experiences, characteristics of research subjects individually or in groups. Data collection technique was using a questionnaire. The method used in sampling was Purposive Sampling. Data Analysis Techniques were through Data Quality Test, classic assumption test and hypothesis testing by analyzing one sample test and independent sample $t$ test. To determine whether the hypothesis was supported or not, by comparing the probability value of the significance level.

\section{Research Findings And Discussion}

This research had three groups of respondents, namely company accountants, accounting educators and accounting students. Questionnaire dissemination was carried out on different days with different payback times because of the different activities and procedures of universities and banks. Details of the questionnaire could be seen in the following table:

Based on the table above it could be seen that the questionnaire returned as many as 90 pieces. 25 questionnaires were distributed to male respondents and 65 questionnaires were distributed to female respondents. This showed that female respondents were better than male respondents. Completed data could be seen in the following table

Table 2. Number of male and female respondents

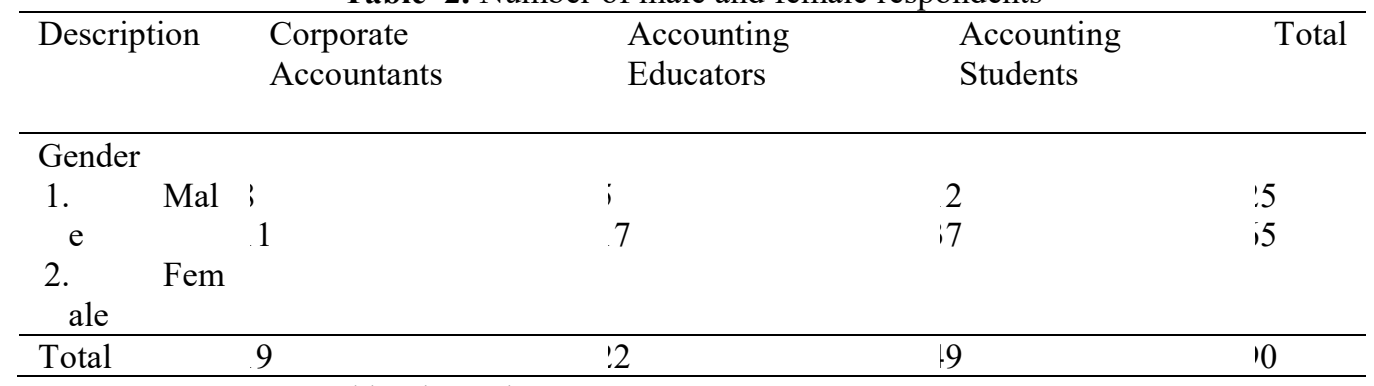

Source: Data processed by the author

The results of the validity test on the statement of Islamic accounting characteristics indicated that all statement items were said to be valid because $r_{\text {count }}$ was greater than $r_{\text {table }}$ $(0,207)$ at a significant level of $5 \%$. This meant that each statement item of Islamic accounting characteristics was declared valid so that data could be further analyzed, except for statement item number 3 . The results of the validity test on Islamic accounting objective statement showed that all statement items were said to be valid becauser $r_{\text {count }}$ was greater than $r_{\text {table }}(0,207)$ at a significant level of 5\%. This meant that each item of Islamic accounting goals statement was declared valid so that the data could be further analyzed.

Table 4.Reliability Test Results

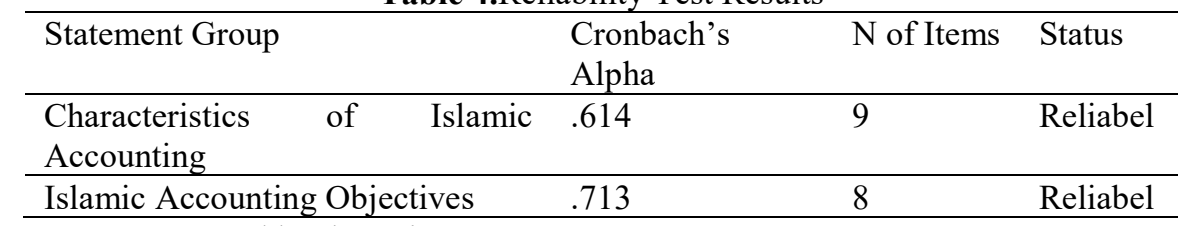

Source: Data processed by the writer 
From the results of the reliability test in the Islamic accounting goal group above, it could be seen that the cronbach's alpha value was greater than 0.60 . This means that all items of Islamic accounting goals statement were declared reliable (reliable) so that data could then be analyzed.

Linear regression test results on Islamic accounting characteristics could be seen in the appendix and in the following figure:

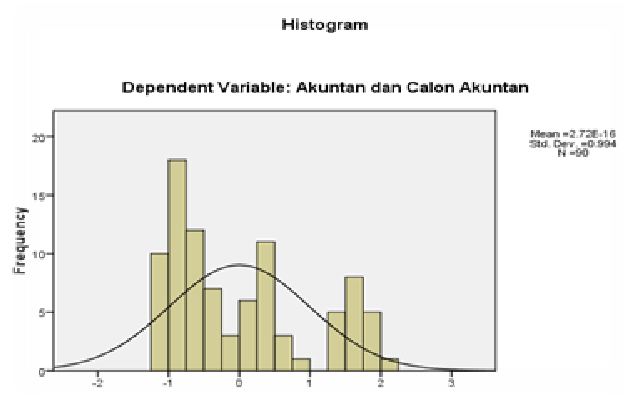

Fig.1. Normality test with linear regression

In the picture above, the data spread around the diagonal line and follows the direction of the diagonal line or the histogram graph showed the pattern of normal distribution, then the regression model met the assumption of normality. The Kolmogorov Smirnov test results in the statement group of Islamic accounting characteristics could be seen in the following table:

From the results of the Kolmogorov Smirnov test, all p-values for Islamic accounting characteristics were greater than $\alpha=5 \%(p>0.05)$, then the residual data distribution was normal. Therefore, testing of hypothesis 1 used parametric statistical analysis One Simple tTest.

The linear regression test results in the group of Islamic accounting goals statement could be seen in the following figure:

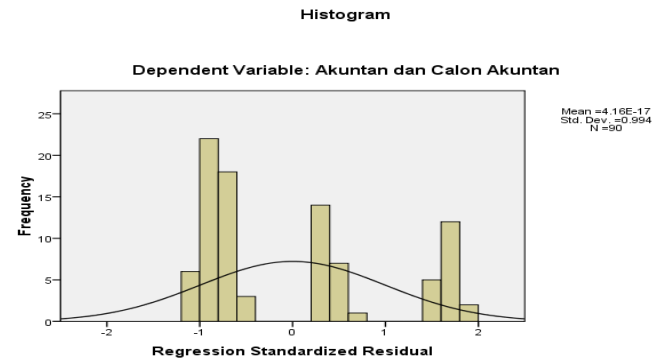

Figure 2: Normality test with linear regression

In the figure above, the data spreadaround the diagonal line and followed the direction of the diagonal line or the histogram graph showed the pattern of normal distribution, and then the regression model met the assumption of normality.

Kolmogorov Smirnov's test on the group of Islamic accounting goals statement could be seen in the following table: 
Table 5. Normality Test Results with Kolmogorov Smirnov

Source: Data processed by the writer

\begin{tabular}{lll}
\hline Statement & Probability Value & Status \\
\hline Islamic Accounting Objectives & 4,834 & Normal \\
\hline
\end{tabular}

From the results of the Kolmogorov Smirnov test, it was known that all p-values for Islamic accounting purposes were greater than $\alpha=5 \%(p>0.05)$, then the residual data distribution was normal. Therefore, testing hypothesis 2 used parametric statistical analysis One Simple t-Test.

The technique used wasLevenestest for equality of variance with the help of the SPSS 16.0 program. The results of homogeneity tests could be seen in the following table:

Table 6. Homogeneity Test Results

\begin{tabular}{lll}
\hline Statement & Probability Value & Status \\
\hline Islamic Accounting Objectives & 0,602 & Homogen \\
\hline Characteristics of Islamic Accounting & 0,032 & Homogen \\
\hline
\end{tabular}

Source: Data processed by the writer

From the results of the calculation of the Levenstest for equality of variance test, it could be seen that all $p$-values $\neg$ for each variable were greater than $\alpha=5 \%(p>0.05)$, so it could be stated that the overall data obtained washomogeneous. Therefore, testing of hypothesis 3 used the parametric analysis of the Independent One Sample t-Test.

The Testing of hypothesis one was done to prove statistically whether the accounting characteristics of Islam were the same as conventional accounting characteristics according to the perceptions of corporate accountants, accounting educators and accounting students.

The complete hypothesis test one could be seen in the appendix and could be seen briefly in the following table:

Table 7. Test Results for Hypothesis One

\begin{tabular}{lllll}
\hline Description & $\mathrm{T}_{\text {count }}$ & $\begin{array}{l}\mathrm{t}_{\text {table }} 5 \\
\%\end{array}$ & $\begin{array}{l}\mathrm{p}- \\
\text { valu } \\
e\end{array}$ & $\begin{array}{l}\text { Descri } \\
\text { ption }\end{array}$ \\
\hline $\begin{array}{l}\text { Perception } \\
\text { about the }\end{array}$ & 2 & & 0 & $\begin{array}{l}\text { rejecte } \\
\text { characteristi }\end{array}$ \\
cs of & & & & $\mathrm{d}$ \\
Islamic & & & & \\
accounting & & & & \\
\hline
\end{tabular}

Source: Data processed by the writer

Because $t_{\text {hitung }}>t_{\text {tabel }}$ was $73,582>3,044$ with $p<0,05$, then $H_{1}$ was rejected. This means that Islamic accounting characteristics were not the same as conventional accounting characteristics according to the perceptions of corporate accountants, accounting educators and accounting students. The testing of hypothesis two was done to prove statistically whether the purpose of Islamic accounting was the same as the conventional objective characteristics according to the perceptions of corporate accountants, accounting educators and accounting students. The complete hypothesis test two could be seen in the appendix and could be summarized in the following table : 
Tabel 8. Test Results for Hypothesis Two

\begin{tabular}{llllllllll}
\hline $\begin{array}{l}\text { Perception about the purpose of Islamic } 101,853 \\
\text { accounting }\end{array}$ & 2,135 & 0,000 & $\begin{array}{l}\mathrm{H}_{0} \\
\text { rejected }\end{array}$ & was
\end{tabular}

\section{Source: Data processed by the writer}

Because $t_{\text {hitung }}>t_{\text {tabel }}$ was $101,853>2,315$ with $p<0,05$, then $H_{1}$ was rejected. This means that the objectives of Islamic accounting were not the same as the objectives of conventional accounting according to the perceptions of corporate accountants, accounting educators and accounting students.

The testing of hypothesis three was done to find out whether or not there was a difference in the average between the two groups of samples, because among each of the sample groups tested were homogeneous, the test used independent parametric sample t-test analysis. The results of the complete hypothesis test could be seen in the appendix and briefly could be seen in the following table :

Table 9. Hypothesis Test Result Three

\begin{tabular}{|c|c|c|c|}
\hline Description & Average & $\begin{array}{l}\text { Probability } \\
\text { Value }\end{array}$ & $\begin{array}{l}\text { Difference } \\
\text { Status }\end{array}$ \\
\hline $\begin{array}{l}\text { Islamic } \\
\text { characteristics }\end{array}$ & & & \\
\hline Corporate Accountants & 22,95 & \multirow[t]{2}{*}{0,867} & \multirow[t]{2}{*}{ Not significant } \\
\hline Accounting Educators & 22,36 & & \\
\hline $\begin{array}{l}\text { Islamic } \\
\text { characteristics }\end{array}$ & & & \\
\hline Corporate Accountants & 22,95 & \multirow[t]{2}{*}{0,725} & \multirow[t]{2}{*}{ Not significant } \\
\hline Accounting Students & 24,59 & & \\
\hline $\begin{array}{l}\text { Islamic accounting } \\
\text { characteristics }\end{array}$ & & & \\
\hline Accounting Educators & 22,36 & \multirow[t]{2}{*}{0,558} & \multirow[t]{2}{*}{ Not significant } \\
\hline Accounting Students & 24,59 & & \\
\hline Islamic Accounting Objectives & & & \\
\hline Corporate Accountants & 24,58 & \multirow[t]{2}{*}{0,514} & \multirow[t]{2}{*}{ Not significant } \\
\hline Accounting Educators & 24,27 & & \\
\hline \multicolumn{4}{|l|}{ Islamic Accounting Objectives } \\
\hline Corporate Accountants & 24,58 & \multirow[t]{2}{*}{0,107} & \multirow[t]{2}{*}{ Not significant } \\
\hline Accounting Students & 25,10 & & \\
\hline \multicolumn{4}{|l|}{ Islamic Accounting Objectives } \\
\hline Accounting Educators & 24,27 & \multirow[t]{2}{*}{0,024} & \multirow[t]{2}{*}{ Not significant } \\
\hline Accounting Students & 25,10 & & \\
\hline
\end{tabular}

Source: Data processed by the writer

Based on the results of the data analysis above, the probability value for the Islamic accounting characteristic variable was more than 0.05 , then $\mathrm{H} 0$ was not rejected and the goal of Islamic accounting was more than 0.05 , then $\mathrm{H} 0$ was not rejected. It could be concluded that there was no difference in perception among company accountants, accounting educators 
and accounting students about the characteristics of Islamic accounting and the purpose of Islamic accounting.

\section{Conclusions}

a. Based on the results of the hypothesis test one, that the characteristics of Islamic accounting were the same as the characteristics of conventional accounting, was rejected. It could be concluded that the accounting characteristics of Islam were not the same as conventional accounting characteristics according to corporate accountants, accounting educators and accounting students. Of the three respondents, accounting students had the best perception of the characteristics of Islamic accounting, because they had the highest mean namely 24.59. Whereas, the means of corporate accountants and accounting educatorswere 22.95 and 22.36 . It could be concluded that the perception of corporate accountants was better than the perception of accounting educators.

b. Based on the results of the hypothesis test two, the hypothesis which stated that the purpose of Islamic accounting was the same as the objective of conventional accounting according to the corporate accountants, accounting educators and accounting students, was rejected.It could be concluded that the purpose of Islamic accounting was not the same as the purpose of conventional accounting according to corporate accountants, accounting educators and accounting students. Of the three respondents, accounting students had the best perception of the characteristics of Islamic accounting, because they had the highest mean namely 24.59. Whereas, the means of corporate accountants and accounting educatorswere 22.95 and 22.36 . It could be concluded that the perception of corporate accountants was better than the perception of accounting educators.

c. Based on the results of hypothesis test three, it was known that the hypothesis which stated that there was not significant difference in perception among the perceptions of corporate accountants, accounting educators and accounting students towards the goals and characteristics of Islamic accounting, was not rejected. It could be concluded that there was no significant difference between the perceptions of corporate accountants, accounting educators and accounting students on the characteristics and objectives of Islamic accounting.

\section{Suggestions}

a. Campus should be able to maintain and even increase the intensity of teaching about Islamic accounting, especially about halal and haram of riba in Islam so that students can improve their human resource and be able to analyze sharia-based principles in Islamic banking in Indonesia, particularly in Medan.

b. Islamic banks should be able to improve performance in the realization of accounting practices in accordance with Islam in the field.

c. The next researchers should be able to use a greater number of respondents and be able to expand the questionnaire distribution area so that the level of generalization will be better.

\section{Acknowledgements}

Thank you to the Department of Accounting, University of Muhammadiyah Sumatera Utara Medan 


\section{References}

[1] Accounting, I. and Elgar, E. (2015) 'Haniffa, R . \& Hudaib , M . ( 2011 ) A Conceptual Framework for Islamic Accounting', (January 2011).

[2] Akhtyamova, N., Panasyuk, M. and Azitov, R. (2015) 'The Distinctive Features of Teaching of Islamic Economics: Philosophy, Principles and Practice', Procedia Social and Behavioral Sciences. Elsevier B.V., 191, pp. 2334-2338. doi: 10.1016/j.sbspro.2015.04.707.

[3] Amran, A. M. et al. (2014) 'The Current Practice of Islamic Microfinance Institutions' Accounting Information System via the Implementation of Mobile Banking', Procedia - Social and Behavioral Sciences. Elsevier B.V., 145, pp. 81-87. doi: 10.1016/j.sbspro.2014.06.013.

[4] Ather, S. M. and Ullah, M. H. (2009) 'Islamic Accounting Systems and Practices', The Cost and Management, XXXVII(6), pp. 9-16. Available at: http://www.academia.edu/download/37734009/Islamic_Accounting_Systems_and_Pra ctices-Final.pdf.

[5] Belabes, A., Belouafi, A. and Daoudi, M. (2015) 'Designing Islamic Finance Programmes in a Competitive Educational Space: The Islamic Economics Institute Experiment', Procedia - Social and Behavioral Sciences. Elsevier B.V., 191, pp. 639643. doi: 10.1016/j.sbspro.2015.04.300.

[6] HAMID, S., CRAIG, R. and CLARKE, F. (1993) 'Religion: A Confounding Cultural Element in the International Harmonization of Accounting?', Abacus, 29(2), pp. 131148. doi: 10.1111/j.1467-6281.1993.tb00427.x.

[7] Hidayah, N. N., Lowe, A. and Woods, M. (2018) 'Accounting and pseudo spirituality in Islamic financial institutions', Critical Perspectives on Accounting. Elsevier Ltd. doi: 10.1016/j.cpa.2018.09.002.

[8] Kamla, R. (2009) 'Critical insights into contemporary Islamic accounting', Critical Perspectives on Accounting, 20(8), pp. 921-932. doi: 10.1016/j.cpa.2009.01.002.

[9] Kamla, R., Gallhofer, S. and Haslam, J. (2006) 'Islam, nature and accounting: Islamic principles and the notion of accounting for the environment', Accounting Forum, 30(3), pp. 245-265. doi: 10.1016/j.accfor.2006.05.003.

[10] Kamla, R. and Haque, F. (2017) 'Islamic accounting, neo-imperialism and identity staging: The Accounting and Auditing Organization for Islamic Financial Institutions', Critical Perspectives on Accounting. Elsevier Ltd, pp. 1-20. doi: 10.1016/j.cpa.2017.06.001.

[11] Napier, C. (2009) 'Defining Islamic accounting: Current issues, past roots', Accounting History, 14(1-2), pp. 121-144. doi: 10.1177/1032373208098555.

[12] Shahul Hameed, M. I. and Rizal, Y. (2005) 'The emerging issues on the objectives and characteristics of Islamic Accounting for Islamic Business Organizations', Malaysian Accounting Review, 4(1), pp. 75-92.

[13] Siswantoro, D., Hameed, S. and Ibrahim, M. (2013) 'Should Islamic Accounting Standard Follow To International Financial Reporting Standards (Ifrs)? a Lesson From Malaysia', Media Riset Akuntansi, Auditing \& Informasi, 13(1), pp. 35-59. doi: 10.1016/S0022-328X(00)00082-6.

[14] Suandi, A. B. (2013) 'Islamic Accounting in Indonesia: A Review from Current Global Situation', Islamic Accounting In Indonesia, pp. 241-264. Available at: http://eb-islam.wg.ugm.ac.id/images/pdf/ShogakuKenkyukaKiyo_77_Suandi.pdf.

[15] Trokic, A. (2015) 'Islamic Accounting; History , Development and Prospects', 
European Journal of Islamic Finance, 3(12), pp. 1-6. doi: 10.13135/2421-2172/1043. 